\title{
Managerial Ability and Managerial Knowledge for Technology Investment in Era 4.0 of SMEs in Surabaya
}

\author{
Ayouvi Poerna Wardhanie ${ }^{1,}$ Didiet Anindita Arnandy ${ }^{2}$ \\ ${ }^{1}$ Information System, Universitas Dinamika, Raya Kedung Baruk 98 , Surabaya 60298, Indonesia \\ ${ }^{2}$ Information System, Universitas Dinamika, Raya Kedung Baruk 98 , Surabaya 60298, Indonesia \\ Email:ayouvi@dinamika.ac.id ${ }^{l}$,didiet@dinamika.ac.id ${ }^{2}$
}

\begin{abstract}
This study aims to analyze how the influence of managerial skills and managerial knowledge on technology investment in the era of the industrial revolution 4.0 on SMEs in the city of Surabaya. The sampling technique used was a survey by distributing questionnaires to respondents. The population selected in this study is the SMEs in the city of Surabaya. The number of samples in this study was 36 people. The data analysis technique used in this study is multiple regression analysis using the Statistical Package for the Social Sciences (SPSS) program. The results of this study are that managerial ability is not a partially significant positive effect on technology investment, but managerial knowledge has a significant positive effect on technology investment. However, simultaneously managerial skills and managerial knowledge have a significant positive effect on technology investment.
\end{abstract}

Keywords: Managerial Ability, Managerial Knowledge, Investment Technology

\section{INTRODUCTION}

Indonesia's competitiveness in the eyes of the world is almost declining. This was written in the report of the World Economy Forum (WEF), Indonesia's Global Competitiveness Index. In 2010-2011, it was ranked 44th out of 139 countries; in 2011-2011, it was ranked 46th out of 142 countries, and in 2012-2013 it was ranked 50th out of 144 countries. However, this changed immediatelyin the 2013-2014 period, in which Indonesia's ranking drastically increased, namely in the 38th rank. This shows that Indonesia is resilient in the face of competition, especially back in the current 4.0 revolution era.

In this era, Indonesia has an excellent opportunity to advance in the competition. This is realized through the business sector, especially in small and medium enterprises (SMEs). According to Law No.20 of 2008, SMEs are divided into two definitions, namely small business, and medium business. Small Business is an entity that has a net worth of more than Rp 50,000,000.00 (fifty million rupiahs) up to a maximum of $\mathrm{Rp}$ 500,000,000.00 (five hundred million rupiahs) excluding land and buildings where it operates and has the proceeds of sales annual amount of more than IDR 300,000,000.00 (three hundred million rupiahs) up to a maximum of IDR 2,500,000,000.00 (two billion five hundred million rupiahs). Medium Business is a business entity that has a net worth of more than Rp 500,000,000.00 (five hundred million rupiahs) up to a maximum of $\mathrm{Rp}$ $10,000,000,000.00$ (ten billion rupiahs) excluding land and buildings where it operates, as well as having sales proceeds. The annual amount of morethan Rp2,500,000,000.00 (two billion five hundred million rupiah) up to a maximum of Rp 50,000,000,000.00 (fifty billion rupiah).

In Indonesia, SMEs experienced very rapid development after the economic crisis that began in 1997, so that SMEs are considered as saviors of the economy. It is said so because SMEs are able to reduce the unemployment rate and provide employment. In addition, SMEs also 


\section{Procedia Business and Financial Technology}

Proceedings of the 2nd International Conference on Business and M anagement of T echnology (ICO N BM T 2020) - Part 2

contribute to regional and state revenues. The era of the industrial revolution 4.0 brought various threats to the Indonesian state because foreign products were easier to enter. Moreover, these products have better quality. Starting from this, encouraging SMEs to be able to improve the quality of products in order to compete with a variety of foreign products that enter.

Surabaya is one of the cities that has developed SMEs well. In 2008, the number of SMEs in Surabaya reached 4.2 million. In 2012 it reached 6.8 million, and finally, in 2016, it reached 9.59 million [1]. By realizing the opportunities of SMEs in the current industrial era 4.0, various efforts are needed to be able to excel in competition. One effort that can be done is technology investment. One of the goals of investing in technology is to increase the efficiency and effectiveness of operational activities, from procurement to delivery, in order to be superior in competition. However, in deciding, there are a number of things that must be considered, including managerial ability, managerial knowledge and, the external environment. It is said so because these three things are considered as factors that influence the success of the design, manufacture, application, and maintenance of the technologyused.

Based on these explanations, research is needed on " Managerial Knowledge and External Environment for Technology Investment in Era 4.0 of SMEs in Surabaya ".

\section{LITERATURE REVIEW}

\subsection{Technology Investment}

City branding as an interesting topic for academics and politicians [2]. It is said so because as a shaper of the image of the place along with the opportunities that exist [3]. In developing a city branding strategy, it must be done carefully and appropriately. This is because city branding is a distinction between one place and another. The city branding strategy can be done through various marketing and branding techniques in order to find out the negative image of a city [4]. City branding can be realized through brand preference.

\subsubsection{Technology Investment Goals}

According to [5], technology investment has several objectives, including maintaining the survival of the company in the current technological era, which is absolutely essential, increasing the efficiency and effectiveness of the company's operational activities and competitive advantage by using technology that has not been applied by competitors. In addition to having a goal, technology investment also has several benefits, namely minimizing costs incurred, avoiding costs, improving product quality, increasing company profits. Technology investment is measured through two indicators namely technological complexity and technology costs [6] and [7]

\subsection{Managerial Ability}

In deciding to invest in these technologies, highmanagerial skills are needed. It was also said because managerial ability as a form of corporate survival was interrupted by technological change [8]. Indicators used to measure managerial skills include employees who are dedicated to digital technology, have information about digital technology, participate in digital technology events, read digital technology articles, and communicate with digital technology providers [9].

\subsection{Managerial Knowledge}

In addition to managerial skills needed, technology investment in the 4.0 era must also be based on managerial knowledge [10]. This is because the manager acts as the main party in making corporate decisions [11]. Especially back to small and medium enterprises (SMEs), which have limitations in terms of information systems, so that the manager (owner) of SMEs must directly be involved in managing a variety of existing information [12]. Managerial knowledge in question is the manager's perception in finding various opportunities related to technology investment in the current 4.0 era. Therefore, managerial knowledge is related to the company's actions towards environmental changes that are carried out by looking for causal factors and ways to overcome [13], [14]. Managerial knowledge can be measured using three indicators, including perceptions of the usefulness oftechnology, trust, and concern for the economy and confidence in costs and benefits [9].

\section{METHOD}

In terms of the problems examined, this research is a type of causality research. Causality research is research that examines a problem about the relationship between independent variables and dependent variables [15]. When viewed from the side of the data obtained, this research is a type of quantitative research. Quantitative research is research that obtains data in the form of numbers and then analyzes. This study consists of three independent variables and one dependent variable. The variables that act as independent variables in this study include managerial ability, managerial knowledge, and external environment, while the variables that act as the 


\section{Procedia Business and Financial Technology}

Proceedings of the 2 nd International Conference on Business and M anagement of T echnology (ICO N BM T 2020) - Part 2

dependent variable in this study are technology investments. The population determined in this study is all SMEs in the city of Surabaya. The number of samples in this study was 36 SMEs in Surabaya. This is due to the limited number of SMEs in the y of Surabaya so that only 36 SMEs were taken. The conceptual framework of this studycan be seen in Figure 1.

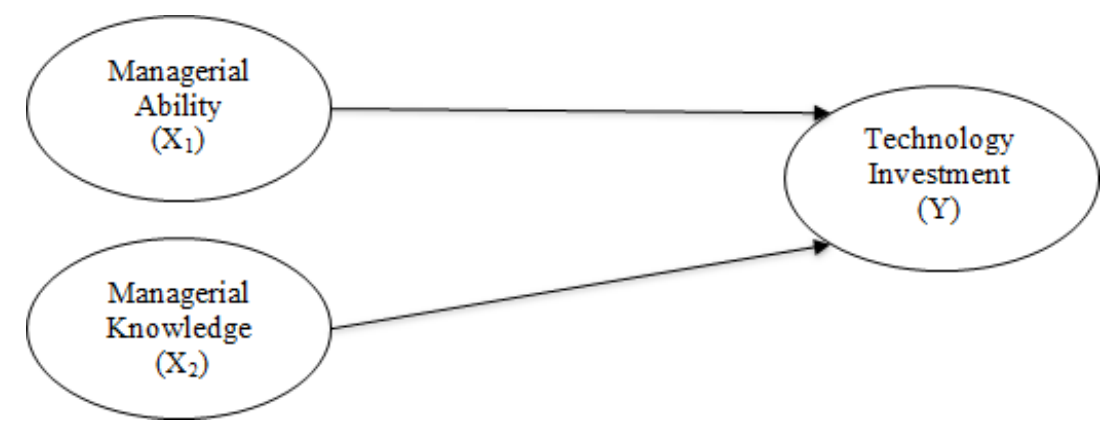

Figure 1 Research ConceptualFramework

Based on the conceptual framework, the hypotheses in this study are as follows:

H1: Managerial Ability has a significant positive effect on Technology Investment

$\mathrm{H} 2$ : Managerial Knowledge has a significant positive effect on Technology Investment

H3: Managerial Ability and Managerial Knowledge has a significant positive effect on Technology Investment

\section{ANALYSIS DATA AND DISCUSSION}

\subsection{Trial Instrument}

\subsubsection{Validity Test}

In the validity test results, it can be concluded that all statement items in this study are valid because it has a rcount

$>$ rtable of 0,3291. Thus the statement items in this study can be reused for further research and then carried out reliability testing.

Table 1 Validity Test Results

\begin{tabular}{|c|c|c|c|}
\hline Item & rcount & rtable & Result \\
\hline Managerial Ability1 & 0,639 & \multirow{10}{*}{0,3291} & Valid \\
\hline Managerial Ability 2 & 0,759 & & Valid \\
\hline Managerial Ability 3 & 0,698 & & Valid \\
\hline Managerial Ability 4 & 0,760 & & Valid \\
\hline Managerial Ability 5 & 0,814 & & Valid \\
\hline Managerial Knowledge 1 & 0,657 & & Valid \\
\hline Managerial Knowledge 2 & 0,928 & & Valid \\
\hline Managerial Knowledge 3 & 0,858 & & Valid \\
\hline Technology Investment 1 & 0,944 & & Valid \\
\hline Technology Investment 2 & 0,940 & & Valid \\
\hline
\end{tabular}

Source: Data Processed (2020)

\subsubsection{Reliability Test}

In the reliability test results, it can be seen that all respondents' answers on the variables in this study are reliable because theyhave a Cronbach's Alpha value > 0,60 .

Thus, the answers from respondents in accordance with reality and the next steps can be made to the normality test.

Table 2 Reliability Test Results

\begin{tabular}{|l|r|r|l|}
\hline Variable & $\begin{array}{c}\text { Cronbach' s } \\
\text { Alpha Value }\end{array}$ & $\begin{array}{c}\text { Cronbach' s } \\
\text { Alpha } \\
\text { Minimum } \\
\text { Value }\end{array}$ & Result \\
\hline \begin{tabular}{l|l|l|} 
Managerial \\
Ability
\end{tabular} & 0,784 & & Reliabel \\
\cline { 1 - 2 } $\begin{array}{l}\text { Managerial } \\
\text { Knowledge }\end{array}$ & 0,749 & 0,670 & Reliable \\
\cline { 1 - 2 } $\begin{array}{l}\text { Technology } \\
\text { Investment }\end{array}$ & 0,873 & & Reliable \\
\hline
\end{tabular}

Source: Data Processed (2020)

\subsection{Classic Assumption Test}

\subsubsection{Normality Test}

In the results of the normality test, it can be seen that the plotting points are around the diagonal line so that the data in this study are normallydistributed. 


\section{Procedia Business and Financial Technology}

Proceedings of the 2nd International Conference on Business and M anagement of T echnology (ICO N BM T 2020) - Part 2

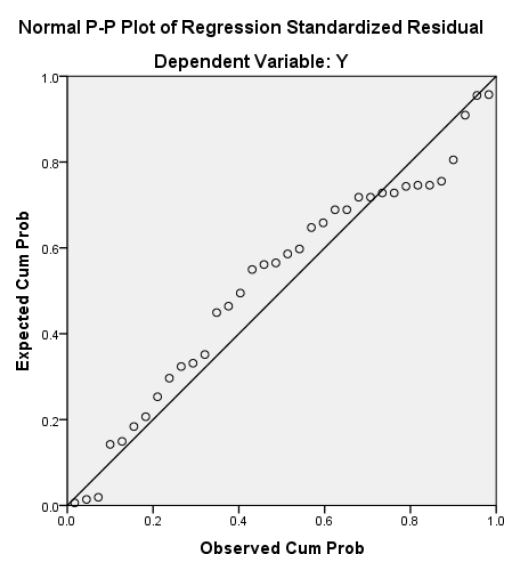

Figure 2 Normality Test Results

\subsubsection{Multicollinearity Test}

correlation between independent variables below 0,90 .

Multicollinearity does not occur because of the

Table 3 Multicollinearity Test Results

\begin{tabular}{|c|c|c|c|c|c|c|}
\hline \multicolumn{7}{|c|}{ Collinearity Diagnostics } \\
\hline \multirow[b]{2}{*}{ Model } & \multirow[b]{2}{*}{ Dimension } & \multirow[b]{2}{*}{ Eigenvalue } & \multirow[b]{2}{*}{ Condition Index } & \multicolumn{3}{|c|}{ Variance Proportions } \\
\hline & & & & $\begin{array}{l}\text { onsta } \\
\text { nt) }\end{array}$ & $\mathrm{X} 1$ & $\mathrm{X} 2$ \\
\hline \multirow[t]{3}{*}{1} & 1 & 2,978 & 1,000 & 0,00 & 0,00 & 0,00 \\
\hline & 2 & 0,015 & 14,212 & 0,16 & 0,11 & 0,99 \\
\hline & 3 & 0,007 & 20,948 & 0,84 & 0,89 & 0,01 \\
\hline
\end{tabular}

Source: Data Processed (2020)

\subsubsection{Linearity Test}

In the linearity test results, it can be seen that all independent variables (independent) in this study are linearly related to the dependent variable (dependent), because all independent variables have a sig. < 0,05. Thus, the next $\mathrm{F}$ test (simultaneous test).

Tabel 4 Linearity TestResults

\begin{tabular}{|c|c|c|c|c|c|c|}
\hline \multicolumn{7}{|c|}{ ANOVA } \\
\hline \multirow{2}{*}{ Model } & $\begin{array}{c}\text { Sum of } \\
\text { Squares }\end{array}$ & df & $\begin{array}{c}\text { Mean } \\
\text { Square }\end{array}$ & F & Sig. \\
\hline 1 & Reg. & 12,505 & 2 & 6,253 & 22,590 & 0,000 \\
\cline { 2 - 7 } & Res. & 9,134 & 33 & 0,277 & & \\
\cline { 2 - 7 } & Total & 21,639 & 35 & & & \\
\hline
\end{tabular}

Source: Data Processed (2020)

\subsection{Multiple Regression Analysis}

\subsubsection{Coefficient of Determination(Adjusted $R^{2}$ )}

In the table of the results of the coefficient of determination can be seen that the independent variable (free) has limited abilityto analyze the dependent variable (dependent) that is equal to $0,552(55,2 \%)$. This can be seen in the Adjusted $\mathrm{R}^{2}$ value of $0,552(55,2 \%)$. This means that as much as $0,448(44,8 \%)$, the dependent variable (dependent) was analyzed by other independent (independent) variables that did not exist in this study. Thus, the $\mathrm{F}$ test is then performed to determine the effect of the independent variables simultaneously on the dependent variable. 


\section{Procedia Business and Financial Technology}

Proceedings of the 2nd International Conference on Business and M anagement of T echnology (ICO N BM T 2020) - Part 2

Table 5 Coefficient of Determination (Adjusted R²)

\begin{tabular}{|c|c|c|c|c|}
\hline \multicolumn{5}{|c|}{ Model Summary } \\
\hline Model & $\mathrm{R}$ & $\begin{array}{c}\mathrm{R} \\
\text { Square }\end{array}$ & $\begin{array}{c}\text { Adjusted R itd. Error of the } \\
\text { Square } \\
\text { Estimate }\end{array}$ \\
\hline 1 & 0,760 & 0,578 & 0,552 & 0,52610 \\
\hline \multicolumn{5}{|c}{ Source: Data Processed (2020) }
\end{tabular}

\subsubsection{F Test (Simultaneous Test)}

In the $F$ test table results, it can be seen that simultaneously all independent variables in this study have significant and positive effects on the dependent variable because of the Fount value of 22,590> Ftable of 3,285 and the value of sig. $<0,05$. Thus the next t-test is performed to find out how much the independent variable in this study is able to influence the dependent variable individually.

Tabel 6 F Test Result

\begin{tabular}{|c|c|c|c|c|c|c|}
\hline \multicolumn{7}{|c|}{ ANOVA } \\
\hline \multirow{2}{*}{ Model } & $\begin{array}{c}\text { Sum of } \\
\text { Squares }\end{array}$ & df & $\begin{array}{c}\text { Mean } \\
\text { Square }\end{array}$ & F & Sig. \\
\hline \multirow{2}{*}{1} & Reg. & 12,50 & 2 & 6,253 & 22,590 & 0,000 \\
\cline { 2 - 7 } & Res. & 9,13 & 33 & 0,277 & & \\
\cline { 2 - 7 } & Total & 21,63 & 35 & & & \\
\hline
\end{tabular}

Source: Data Processed (2020)

\subsection{3. the t-Test (Partial Test)}

Tabel 7 test Result

\begin{tabular}{|c|c|c|c|c|c|c|c|c|}
\hline \multicolumn{9}{|c|}{ Coefficients } \\
\hline \multirow{2}{*}{\multicolumn{2}{|c|}{ Model }} & \multicolumn{2}{|c|}{$\begin{array}{c}\text { Unstandardized } \\
\text { Coefficients }\end{array}$} & $\begin{array}{r}\text { Standardized } \\
\text { Coefficients }\end{array}$ & \multirow[b]{2}{*}{$\mathrm{t}$} & \multirow[b]{2}{*}{ Sig. } & \multicolumn{2}{|c|}{ Collinearity Statistics } \\
\hline & & B & Std. Error & Beta & & & Tolerance & VIF \\
\hline \multirow[t]{3}{*}{1} & (Constant) & $-0,375$ & 0,79 & & $-0,470$ & 0,64 & $-0,37$ & 0,79 \\
\hline & $\mathrm{X} 1$ & 0,222 & 0,20 & 0,132 & 1,071 & 0,29 & 0,22 & 0,20 \\
\hline & $\mathrm{X} 2$ & 0,806 & 0,14 & 0,698 & 5,665 & 0,00 & 0,80 & 0,14 \\
\hline & & & & dent V & & & & \\
\hline
\end{tabular}

Source: Data Processed (2020)

\section{DISCUSSION}

\section{H1: Managerial Ability has a significant positive effect on Technology Investment}

The managerial ability variable does not significantly influence the technology investment variable because ithas a sig value. amounting to 0,292>0,05. In addition, it can be seen that the tstat value of the variable Managerial Ability is 1,071> ttable of 2,035. Based on these results, the hypothesis stating, "Managerial Ability has a significant positive effect on Technology Investment," was declared rejected.
H2: Managerial Knowledge has a significant positive effect on Technology Investment

The managerial knowledge variable significantly influences the technology investment variable because it has a sig value. at $0,000<0,05$. In addition, it can be seen that the tstat variable value of the product variable is $5,665>$ table is 2,035. Based on these results, the hypothesis stating "Managerial Knowledge has a significant positive effect on Technology Investment" is accepted.

\section{H3: Managerial Knowledge and External Environment has a significant positive effect on Technology Investment}




\section{Procedia Business and Financial Technology}

Proceedings of the 2nd International Conference on Business and M anagement of T echnology (ICO N BM T 2020) - Part 2

The attitude variable towards brand and brand image significantly influence brand equity variable because it has sig value. at $0,000<0,05$. In addition, it can be seen that the Fcount value of 22,590> Ftable of 3,285. Based on these results, the hypothesis stating "Managerial Ability and Managerial Knowledge has a significant positive effect on Technology Investment" is accepted.

\section{CLOSING}

\subsection{Conclusion}

Based on the results and discussion of data analysis, two things can be concluded, as follows:

1) Technological investment in SMEs in the city of Surabaya is not affected by managerial ability by the owners of SMEs.

2) Investment technology in SMEs in the city of Surabaya based on managerial knowledge by the owners of SMEs.

\subsection{Suggestion}

Based on the results of the study, there are a number of suggestions given by researchers to two parties, namely further research and SMEs in the city of Surabaya as follows:

1) For Further Research

It was extending this research by using other variables beyond the variables described in this study. This is because the independent variable in this study is only able to explain the dependent variable by $55,2 \%$, which means that there are still other variables of $44,8 \%$, which have more influence on the dependent variable in this study. In addition, it is advisable to use other methods of retrieving data outside the questionnaire, for example, by interview. This is in order to obtain more varied and more accurate data because the respondent's answers are only in accordance with the questionnaire provided and are closed in nature.

2) For SMEs in the city ofSurabaya

Increasing managerial ability and managerial knowledge. Especially in managerial skills. This is in accordance with the results of the $t$ test (partial test) which factors do not affect the technology investment. There are several efforts that can be made by the city government of Jember. The first strategy is a strategy to improve managerial skills is to have a dedication of digital technology, have information about digital technology, participate in digital technology events, read digital technology articles and communicate with technology providers. The second strategy is a strategy to strengthen managerial knowledge is to have sufficient perception in using technology, trust and have a sense of caution related to the economy and have full confidence in the costs incurred and the benefits obtained.

\section{REFERENCES}

[1] T. Aquinus, "Pertumbuhan UKM Surabaya Terus Meningkat," 2018. [Online]. Available: preneur.trubus.id. [Accessed: 16-Aug-2019].

[2] B. C. Page, S. B., Stone, M. M., Bryson, J. M., \& Crosby, "Public value creation by cross-sector collaborations: A framework and challenges of assessment," Public Adm., vol. 93(3), pp. 715-732, 2015.

[3] M. Kavaratzis, "Cities and their brands: Lessons from corporate branding," Place Brand. Public Dipl., vol. 5(1), pp. 26-37, 2009.

[4] R. Paddison, "City marketing, image reconstruction and urban regeneration," Urban Stud., vol. 30(2), pp. 339-350, 1993.

[5] P. W. dan U. H. Hendarti, Handayani, "Analisis Fungsionalitas Open Source Software ERP untuk Pengembangan Modul Pembelajaran ERP," vol. 7 (2), pp. 118-125, 2011.

[6] P. L. M. A.M. Adrian, S.H. Norwood, "Producers' perceptions and attitudes toward precision agriculture technologies," Comput. Electron. Agric, vol. 48, pp. 256- 271, 2005.

[7] J. D. L. M.H. Castle, B.D. Lubben, "Factors Influencing the Adoption of Precision Agriculture Technologies by Nebraska Producers Retrieved at: University of Nebraska Presentations," 49, 2016.

[8] T. E. S. J.B. Sorensen, "No TitleAging, obsolescence, and organizational innovation," Adm. Sci. Q., vol. 45 (1), pp. 81-112, 2000.

[9] F. Annosia, M. C., Brunettab, F., Montic, A., Nati, "Is the trend your friend? An analysis of technology 4.0 investment decisions in agricultural SMEs," Comput. Ind., vol. 109, pp. 59-71, 2019.

[10] J. P. Walsh, "Managerial and organizational cognition: notes from a trip down memory lane," Organ. Sci., vol. 6 (3), pp. 280-321.

[11] C. Y. C. W.T. Hsu, H.L. Chen, "Internationalization and firm performance of SMEs: the moderating effects of CEO attributes," J. World Bus., vol. 48 (1), pp. 1-12,2013.

[12] W. B. T. L. Tihanyi, "Information-processing demands and the multinational enterprise: a comparison of foreign and domestic earnings estimates," J. Bus. Res., vol. 58 (3), pp. 285-292, 2005. 


\section{Procedia Business and Financial Technology}

Proceedings of the 2 nd International Conference on Business and M anagement of T echnology (ICON BM T 2020) - Part 2

[13] K. E. W. R.L. Daft, "Toward a model of organizations as interpretation systems," Acad. Manag. Rev., vol. 9, pp. 284-295, 1984.

[14] W. Ocasio, "Towards an attention-based view of the firm," Strateg. Manag. J., vol. 18, pp. 198-206, 1997.

[15] Sugiyono, Metode Penelitian Kuantitatif Kualitatif Dan R\&D. Bandung: Alfabeta, 2012. 